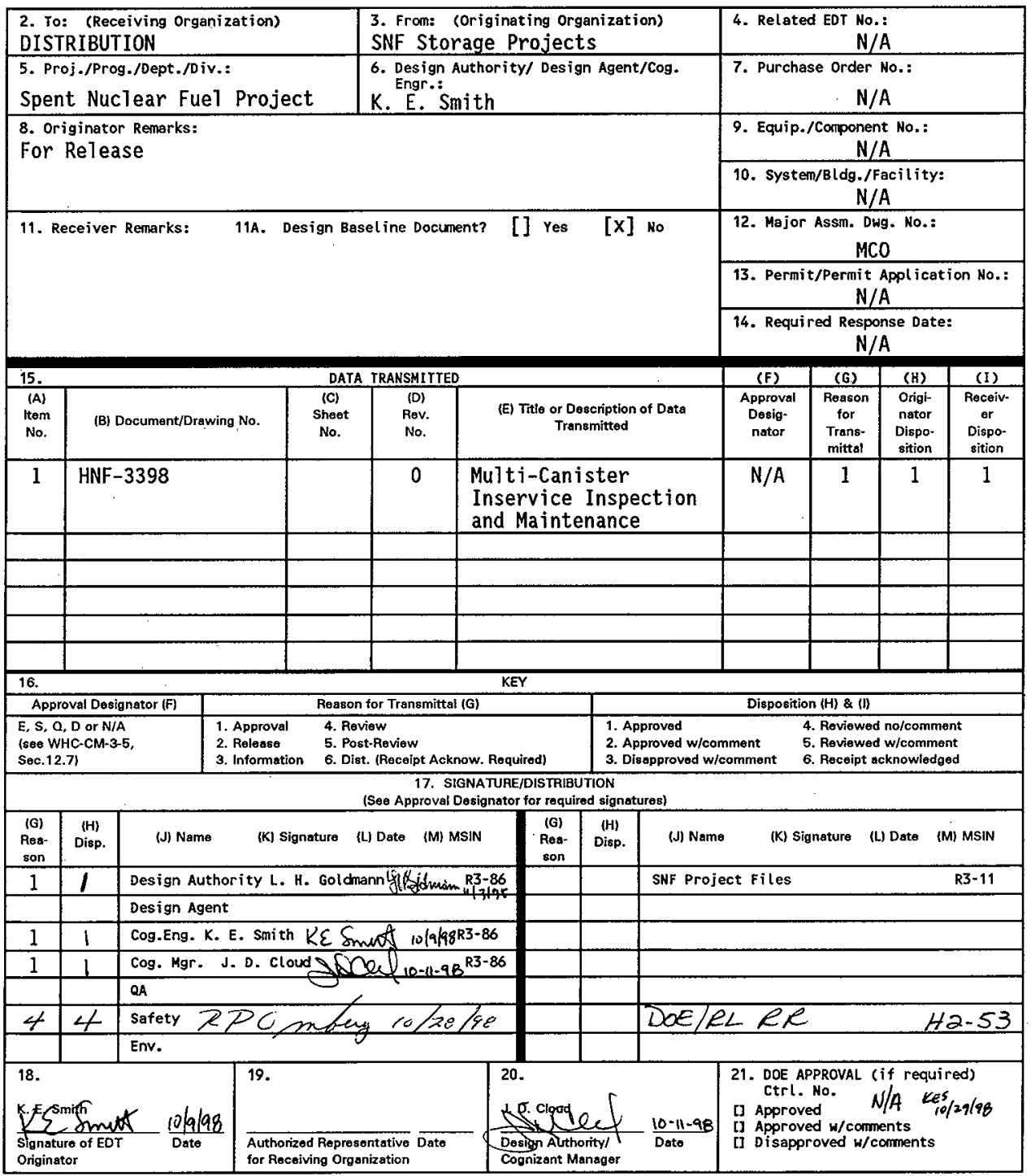

BD-7400-172-2 (05/96) GEF097 


\title{
Multi-Canister Overpack Inservice Inspection and Maintenance
}

\author{
K. E. Smith \\ DE\&S Hanford, Inc., Richl and, WA 99352 \\ U.S. Department of Energy Contract DE-AC06-96RL13200 \\ EDT/ECN: 625781 \\ UC: 600 \\ Org Code: 2T340 \\ Charge Code: 105532/AA30 \\ B\&R Code: EW7040000 \\ Total Pages: 6
}

Key Words: MCO, Spent Fue1, ASME, Packaging, Container, Issue, Inspection, Maintenance, Corrosion

Abstract: The factors to be considered in establishing inservice inspection and maintenance requirements for the Multi-Canister Overpack (MCO) include evaluating the likelihood of degradation to the MCO pressure boundary due to erosion and corrosion, reviewing commercial practice for NRC licensed spent nuclear fuel storage systems, and examining the individual MCO components for maintenance needs. Reviews of the potential for MCO erosion and corrosion conclude that neither will pose a threat to the MCO pressure boundary. Consistent with commerical practice for spent fuel storage systems, the MCO closure weld will be helium leak tested prior to placement in interim storage. Beyond the CSB facility related monitoring plans (radiological monitoring, emissions monitoring, vault cooling data, etc.), no inservice inspection or maintenance of the MCO is required during interim storage.

TRADEMARK DISCLAIMER. Reference herein to any specific comercial product, process, or service by trade name, trademark, manufacturer, or otherwise, does not necessarily constitute or imply its endorsement, recomendation, or favoring by the United States Government or any agency thereof or its contractors or subcontractors.

Printed in the United States of America. To obtain copies of this document, contact: Document Control Services, P.0. Box 950, Mailstop H6-08, Richland WA 99352, Phone (509) 372-2420; Fax (509) 376-4989.
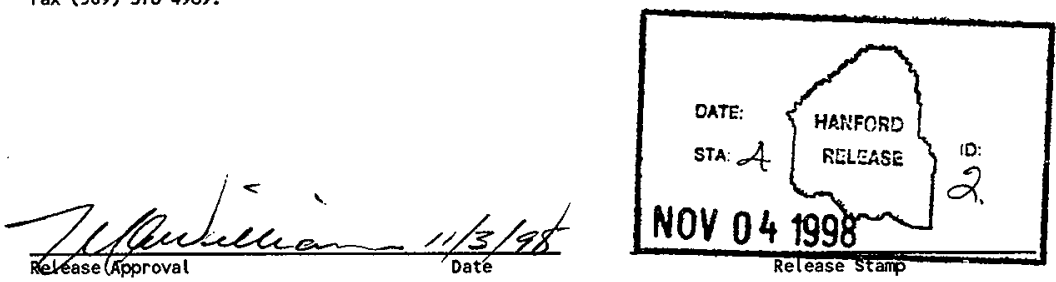

Approved for Public Release 


\section{Issue Closure Package}

Issue: MCO Inservice Inspection and Maintenance

Lead:

K. E. Smith

$K \varepsilon$ Sintt $10 / 9 / 98$

MCO Implementation

Manager, DE\&S Hanford

\section{Approvals:}

Chief Engineer:

A. M. Segrest

DE\&S Hanford

Technical Operations:

J. A. Swenson Manager

DE\&S Hanford

Construction Projects:

A. R. Hollins

Manager

DE\&S Hanford
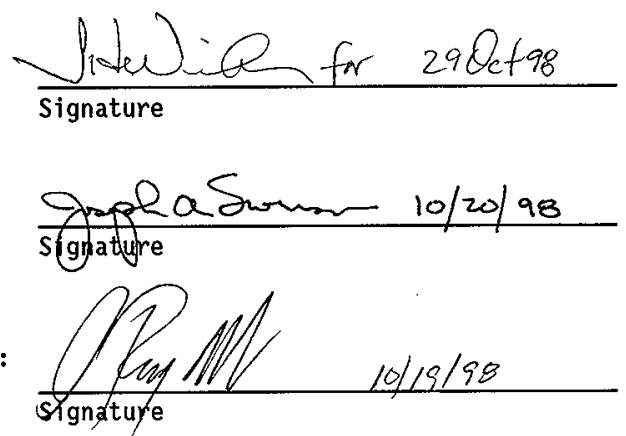

Nuclear Safety:

Robert G. Morgan

Manager

DE\&S Hanford

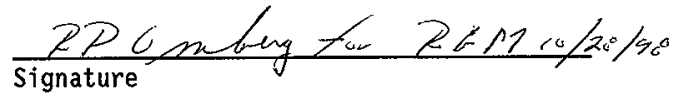

MCO Design Authority:

L. H. Goldmann

DE\&S Hanford

Ginstistotnom 10/9/98

Signature 
HNF-3398, Rev. 0

\author{
MULTI-CANISTER OVERPACK \\ INSERVICE INSPECTION AND MAINTENANCE
}

\title{
Introduction
}

After removal of water during the cold vacuum drying operation and placement of the welded cover cap over the mechanical closure, the Multi-Canister overpack (MCO) will be placed in interim storage at the Canister Storage Building (CSB) for up to 40 years. Although the MCO is stored passively with no moving parts in an environmentally benign atmosphere, the need for inservice inspection and maintenance should be evaluated and documented. The factors to be considered in establishing inservice inspection and maintenance requirements for the $M C O$ include evaluating the likelihood of degradation to the MCO pressure boundary due to erosion and corrosion, reviewing commercial practice for NRC Ticensed spent nuclear fuel storage systems, and examining the individual MCO components for maintenance needs.

\section{Discussion}

\section{A. Erosion and Corrosion}

Water both external and internal to the MCO will be removed at the Cold Vacuum Drying Facility (CVDF). Following completion of the CVD process, the MCO will be dry since the water vapor inside the MCO will be consumed by the bare uranium metaT. During interim storage, potential interactions between the CSB storage tube material, the $\mathrm{MCO}$, and water are precluded as the storage tubes are kept dry. The MCO sees no erosion during interim storage since it will only experience convective air currents on the outside of the MCO and flow of the captured ambient gasses inside the MCO. These gentle currents are powered by a fraction of the radiolytic decay heat of the fuel and do not result in velocities sufficient to cause erosion.

Corrosion aspects of the MCO materials have been considered in the design documentation (Reference 1). The two main areas of concern include intergranular corrosion of the welded areas of the stainless steel shell and base metal corrosion. The enabling features for inter-granular corrosion include (1) halogen availability, (2) water availability at the heat affected zone, and (3) sensitization of the heat affected areas of the weld materials. Steps have been taken to assure that these enablers are appropriately absent from the MCO before and after the CVD process.

Materials in contact with the MCO during manufacturing and operations activities are prescribed to be of low halogen content. This low halogen requirement begins with the manufacture of the MCO and continues through to the operations of the CVD and the CSB. After cold vacuum drying is complete, essentially no water is available for use in galvanic conductivity or mass 
HNF-3398, Rev. 0

transport of corrosion reactants or products inside the MCO. Later in the CSB, the storage tubes are kept dry and water is not allowed in contact with the MCOS. To minimize the potential for sensitization of weld heat affected zones, low carbon content stainless steels are used to assist in the precipitation control of chromium carbides in the material. These three preventitive measures combined with properly developed and implemented weld procedures will effectively assure that inter-granular corrosion of the welds and heat affected areas will not occur.

Base metal corrosion of the MCO pressure boundary materials also has been reviewed (Reference 1). The above mentioned measures of low halogen availability and an absence of free water in contact with the MCO materials during interim storage assure a very low general corrosion rate for the MCO pressure boundary.

An additional review of the potential for MCO degradation due to corrosion related mechanisms was performed by the Technical Assistance Group (TAG) on behalf of the U.S. Department of Energy, Richland Operations (RL) (Reference 2). The TAG review considered general corrosion, as well as localized corrosion phenomena including intergranular attack, stress corrosion cracking, hydrogen embrittlement, and pitting/crevice corrosion. The TAG review concludes that corrosion does not pose a threat to the MCO pressure boundary.

Because neither erosion nor corrosion will cause sufficient material loss to threaten the integrity of the MCO pressure boundary during interim storage at the CSB, inservice inspections to ascertain material erosion or corrosion are not planned.

\section{B. Commercial Spent Nuclear Fuel Practice}

The CSB facility has documented various monitoring and inspection functions to be performed in HNF-2332, "CSB Monitoring Strategy." Although the specific monitoring program to be applied to the MCOs is under review and will likely vary from that described in this document, the document does outline other facility monitoring programs including facility radiological surveys, CSB vault cooling data, select CSB storage tube monitoring, HVAC system data, and radioactive emissions monitoring data.

The NRC has published draft Standard Review PTans as NUREG-1536 for Dry Cask Storage Systems, and NUREG-1567 for Spent Fuel Dry Storage Facilities. While NUREG-1536 suggests routine periodic visual surface and weld inspections of the storage cask, neither document addresses inspection requirements for the spent fue 1 inner container, which is loaded in the storage cask.

In order to understand how the NRC guidelines have been applied in practice, a review of inservice inspection requirements contained in 1 icensing documents for various commercial spent nuclear fuel storage systems was performed by $\mathrm{Mr}$. Alan Hosler of SAIC. The survey results are presented in the table below: 


\begin{tabular}{|c|c|c|}
\hline Qoncept & Bogument & 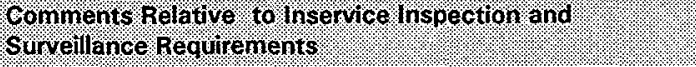 \\
\hline $\begin{array}{l}\text { Foster Wheeler Energy } \\
\text { Applications }\end{array}$ & EA-86/20, Rev $1 A$ & $\begin{array}{l}\text { Section } 10.2 .3 .14 \text { of EA-86/20 states that the SST shield plug seals } \\
\text { should be inspected for material degradation at a } 5 \text {-year minimm } \\
\text { interval. Section } 10.2 .3 .11 \text { requires weekty inspection of the air } \\
\text { inlets. }\end{array}$ \\
\hline $\begin{array}{l}\text { Pacific Nuclear Fuel } \\
\text { Services (PNFS)-- } \\
\text { VECrRA, NUHOMS } \\
\text { (Calvert Cliffs, HB } \\
\text { Robinson) } \\
\text { In the PNFS design } \\
\text { the spent fuel is } \\
\text { loaded into a dry } \\
\text { storage container } \\
\text { (DSC) which is then } \\
\text { seal welded. The DSC } \\
\text { is stored in } \\
\text { horizontal storage } \\
\text { module. }\end{array}$ & $\begin{array}{l}\text { NUH-003, Rev } 2 \text { and } \\
\text { BGE-01-126, Rev } 1\end{array}$ & $\begin{array}{l}\text { The NUS generic application (NUH-003) requires, in Section } 10.2 .3 \text {, } \\
\text { that visual inspection of the HSM air inlets and outlets be } \\
\text { performed every } 4 \text { days. The NRC=S SER for Calvert Cliffs requires } \\
\text { the inspection every } 24 \text { hours and after high winds (reference to } \\
\text { high winds is missing from the Calvert cliffs technical } \\
\text { specifications). } \\
\text { The materials license for Calvert Cliffs exempts the licensee from } \\
\text { the provisions of } 10 \text { CFR } 72.122(i) \text { with respect to providing } \\
\text { instrumentation and control systems for the DSC and HSM during } \\
\text { storage operations. The license requires that the results of the } \\
\text { one-time hel ium leak rate testing of the closure welds should not } \\
\text { exceed } 10^{-4} \text { atm-cc/s. } \\
\text { The technical specifications for HB Robinson requires that the an } \\
\text { HSM have a loacled DSC removed at } 5 \text { and } 10 \text { years for visual } \\
\text { inspection of the interior concrete surface of the HSH. The } \\
\text { technical specifications also provide the utility the options to } \\
\text { install thermocouples in some or all DSCs and HSMs but the } \\
\text { installation is not a requirement of the technical specifications. }\end{array}$ \\
\hline $\begin{array}{l}\text { Pacific Sierra } \\
\text { Nuctear (PSN) } \\
\text { (Patisades) } \\
\text { In the PSN design the } \\
\text { spent fuel is loaded } \\
\text { into a multi-assenbly } \\
\text { sealed basket (MSB) } \\
\text { which is then seal } \\
\text { welded. The MSB is } \\
\text { stored in a } \\
\text { ventilated concrete } \\
\text { cask (VCC). }\end{array}$ & $\begin{array}{l}\text { PSN-CPC-0114.002 and } \\
\text { PSN-89-001, Rev } 2 A \\
\text { NRC SER, 3/29/91 }\end{array}$ & $\begin{array}{l}\text { PSN } 89-001 \text {, Section } 9.2 \text { and the CPCo SAR, Section } 10.2 .3 \text {, require } \\
\text { annual visual inspection of the cask exterior surface for chipping, } \\
\text { spalling, or other surface defects and weekly inspection of the air } \\
\text { vents. } \\
\text { The NRC=s SER for the PSN design requires on a one-time basis after } \\
5 \text { and } 10 \text { years that all internal surfaces of one VSC be inspected to } \\
\text { identify potential airflow blockage and material degradation. } \\
\text { As the MSB is a seal-welded system, the NRC only reguires the one- } \\
\text { time hel ium leak test of each MSB closure weld (10 } 4 \text { atm-cc per } \\
\text { second at a pressure differential of } 0.5 \text { atmospheres). }\end{array}$ \\
\hline $\begin{array}{l}\text { Transnuclear } \\
\text { (TN-40) } \\
\text { Northern States Power } \\
\text { - Prairie Island } \\
\text { In the TN design fuel } \\
\text { is loaded into the } \\
\text { storage cask. The } \\
\text { TN-40 design uses a } \\
\text { single closure lid } \\
\text { incorporating two } \\
\text { metallic D-ring } \\
\text { seals. }\end{array}$ & $\begin{array}{l}\text { Prairie Island ISFSI } \\
\text { SAR }\end{array}$ & $\begin{array}{l}\text { Section } 10.3 .8 \text { requires a visual surveillance of the ISFSI on a } \\
\text { quarterly basis to determine no significant damage or deterioration } \\
\text { of the exterior of the casks has occurred. } \\
\text { The Prairie Island technical specifications require that the results } \\
\text { of the one-time hel ium leak rate testing of the closure should not } \\
\text { exceed } 10^{-5} \text { atm-cc/s (as opposed to } 10^{-4} \text { for the seal-welded cask). } \\
\text { The technical specifications for prairie Island require that the } \\
\text { pressure between the cask double seals be checked daily at the alarm } \\
\text { board to ensure the helium atmosphere in the cask is maintained. }\end{array}$ \\
\hline $\begin{array}{l}\text { Castor V/21 } \\
\text { Virginia Power B } \\
\text { Surry } \\
\text { The Castor } V / 21 \text { is a } \\
\text { metal cask with a } \\
\text { bolted closure }\end{array}$ & $\begin{array}{l}\text { Surry Materials } \\
\text { License }\end{array}$ & $\begin{array}{l}\text { The technical specifications included with the materials license for } \\
\text { Surry requires a pressure switch monitor the interlid pressure with } \\
\text { a setpoint of } 4 \text { bar. } \\
\text { ILOs are to be located on the boundary of the ISFSI and they are to } \\
\text { be read on a quarterly basis. No other IsI requirements are } \\
\text { established in the technical specifications. }\end{array}$ \\
\hline $\begin{array}{l}\text { Public Service Co. of } \\
\text { Colorado - Fort st. } \\
\text { Vrain }\end{array}$ & $\begin{array}{l}\text { Fort St. Vrain SAR } \\
\text { and SER }\end{array}$ & $\begin{array}{l}\text { Section } 10.1 .2 \text { for the SAR requires no surveillance of the fuel } \\
\text { storage container (FSC). However, the Fort St. Vrain technical } \\
\text { specifications require sampl ing and testing of the metal 0-ring } \\
\text { seals. This is applied to a sample of } 6 \text { FSCs at a } 5 \text {-year interval. } \\
\text { The technical specifications for Fort st. Vrain also require } \\
\text { inspection of the cooling inlets and outlets every seven days. }\end{array}$ \\
\hline
\end{tabular}


Most commercial casks are neither instrumented nor connected to the facility with surveillance or control channels. For commercial spent fuel canisters that rely on a final welded boundary similar to the MCO, a one-time helium leak test of the final closure weld is required. Subsequent inspections to verify weld integrity or leaktightness are not specified. Commercial spent fuel canisters requiring periodic (every 5 years) inspection for leaktightness are those that employ dual mechanical seals, which is not the case for the MCO. The final closure weld on the MCO will be helium leak tested to $1 \times 10^{-7}$ $\mathrm{scc} / \mathrm{sec}$. This approach is consistent with commercial spent nuclear fuel practice.

No commercial spent fuel storage facilities are applying ASME section XI to the systems or facilities. ASME Section XI "Rules for Inservice Inspection of Nuclear Power Plant Components" is written for operating nuclear reactors. Application of ASME Section XI is not a requirement for the MCO and would be inconsistent with commercial practice.

\section{Maintenance}

In accordance with the MCO Performance Specification, HNF-S-0426, the MCO is designed to minimize the need for preventative maintenance throughout its design life. Once the cover cap is welded over the mechanical closure at the CSB, the functioning components of the $M C 0$, such as the seals, rupture disk, and process valve plugs are inactive and no longer accessible for repair/replacement. As such, there are no components of the MCO that require maintenance during interim storage.

\section{Conclusion}

Beyond those facility related items mentioned in the CSB monitoring plan, no inservice inspection or maintenance of the $M C O$ is required while the MCOs are in storage at the CSB. Degradation of the MCO pressure boundary due to erosion and corrosion is highly unlikely. Consistent with commercial spent nuclear fuel storage practice, the MCO final closure weld will be helium Teak tested prior to placement in storage.

\section{References}

1. HNF-S-0426, "Specification for the Spent Nuclear Fuel Multi-Canister Overpack", Revision 4

2. Memo, R. G. Ballinger, TAG, to Phil Loscoe, RL, "Comments Related to D.A. Powers Trip Report, Corrosion Issues", dated March 20, 1998. 


\section{DISTRIBUTION COVERSHEET}

Subject: MCO ISSUE PAPERS PER ATTACHED DISTRIBUTION INDEX

\section{DISTRIBUTION}

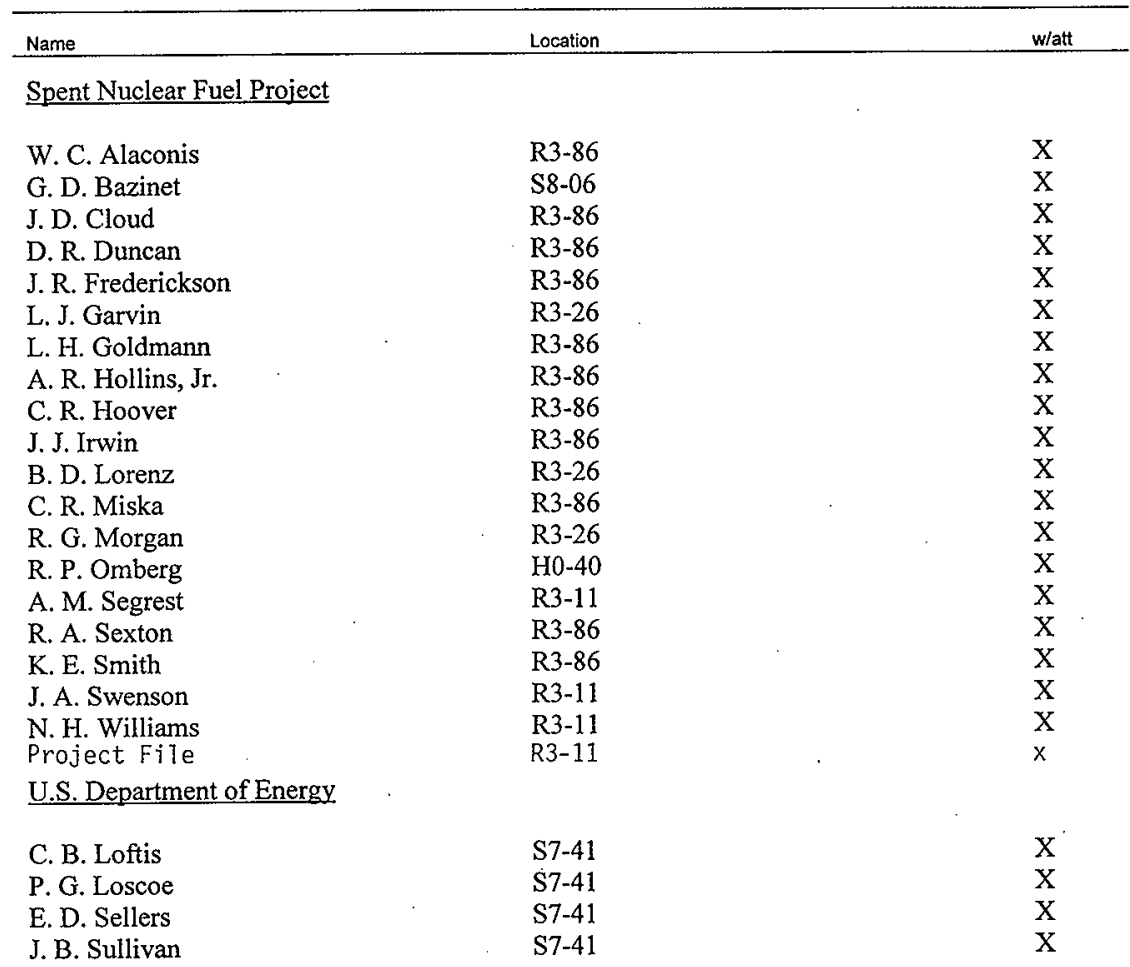




\section{DISTRIBUTION INDEX}

The Multi-Canister Overpack Issue papers listed below are being distributed as a package to facilitate future reference and use by SNF Project personnel. The following issue papers are attached:

1. HNF-2876, Oxygen Gettering Issue Closure Package

2. HNF-3265, MCO Number of Shield Plug Ports

3. HNF-3399, MCO Necessity of the Rupture Disk

4. HNF-3267, MCO Dual Pressure Rating

5. HNF-3293, MCO Ultrasonic Examination of Closure Weld

6. HNF-3354, MCO Monitoring Issue Closure Package and HNF-3312, MCO Monitoring Activity Description

7. HNF-3292, MCO Sealing Configuration

8. HNF-3266, MCO Design Pressure Rating

9. HNF-3255, ASME Code Requirements for MCO Design and Fabrication

10. HNF-3398, MCO Inservice Inspection and Maintenance

11. HNF-3420, MCO Internal HEPA Filters

12. HNF-3036, Low Reactive Surface Area Issue Closure Package

13. HNF-3270, MCO Pressure Testing 